\title{
Writing Italies, an Introduction
}

\section{Ilaria Vanni, University of Technology Sydney}

I feel uncomfortable when I travel to Italian universities and meet elderly, and not so elderly, baroni, like those who taught me as an undergraduate. They ask polite questions: 'So, what do you do?' And when I reply 'Cultural Studies,' they look a little amused and a little blank. Some recover quickly to ask: 'You mean letteratura?' Others, more adventurous perhaps, nod: 'Like cultural anthropology.' Some want to know if cultural studies includes filologia romanza. At times I try to translate in Italian: 'Studi Culturali,' but that creates some confusion with Beni Culturali, a corso di laurea that is apparently now taught in every single Italian university. Unlike cultural studies.

In their introduction to Italian Cultural Studies (1996: 2), David Forgacs and Robert Lumley noted how the fundamental untranslatability of cultural studies in Italian is due to different academic taxonomies, which mean that Italian universities would teach as separate disciplines what in British and US institutions is called cultural studies. This institutional separation has also posed a certain difficulty for people hoping to engage with a holistic approach: historians of literature engage with literature, and anthropologists with cultural rituals, customs and practices. Translated into Italian Studies at a global level this approach has meant that the study of canonic letteratura e lingua has predominance in Italian departments worldwide (Galli Stampino 2001; West 2001).

This dichotomy also reflects two different approaches to culture: on one hand a 'strong association with education and literacy, and more generally with "print culture" 
(Forgacs and Lumley 1996: 3), and on the other hand, the idea that everyday practices are explicable as either folklore or cultura di massa. This distinction finds its origins in a humanist-intellectualist tradition associated with the philosophers Benedetto Croce (1866-1952) and Giovanni Gentile (1975-1944, the designer of the 1923 school reform under Mussolini's government), which identified culture with the production of intellectuals (Forgacs and Lumely 1996: 3). Until the 1960s, the decade when, during Italy's economic boom, a fringe group of scholars including Umberto Eco started to introduce new intellectual traditions and new disciplines, such as semiotics, to studies of la cultura di massa (Forgacs and Lumley 1996: 6), culture in Italy meant predominantly the history of Italian literature and, to a certain extent, the arts, but only of the past. La cultura di massa itself was shunned as the evil impoverishment of cultura caused by commodification (Forgacs and Lumley 1996: 6). La cultura di massa was opposed in its inauthenticity to la cultura popolare, or folklore, to which Antonio Gramsci (1891-1937) devoted several pages of his Prison Notebooks, which was studied in the post-WW II years by innovative anthropologists such as Ernesto De Martino and Alberto Maria Cirese. ${ }^{1}$ The questions asked of me, and of what I do, by numerous baroni belong to this cultural tradition.

On one level my exchanges with baroni make me happy I left l' Università italiana and its disciplinary power silos. Yet those exchanges have also influenced my reflections on what it might mean today to speak of Italian cultural studies. Is there a specific genealogy to the study of cultures in Italy that intersects with the Anglophone definition of cultural studies? Is Italian cultural studies confined to cultural practices in Italy, or does it expand to include the cultural practices of the Italian diaspora? If there is an Italian cultural studies tradition, where is it? What do Italian cultural studies academics write about?

I am not the first, of course, to explore the idea of Italian Cultural Studies by posing these questions. The middle and late 1990s saw a growing number of academics on both sides of the Atlantic becoming involved in a move to define and map Italian cultural studies, although it is important to note that most of this mapping has appeared in

\footnotetext{
${ }^{1}$ See Forgacs and Nowell-Smith's English edition, Selections from Cultural Writings (1999). For an overview of Gramsci's influence on Italian anthropology, see Nicoletta Pireddu's chapter, the 'Anthropological Roots of Italian Cultural Studies' (Parati and Lawton 2001).
} 
English, rather than Italian. Forgacs and Lumley's Italian Cultural Studies (1996) was quickly followed by Allen and Russo's Revisioning Italy, National Identity and Global Culture (1997), and Dombroski's special edition of Annali d'italianistica titled Italian Cultural Studies in 1998. Dartmouth College, in New Hampshire, organised the first conference of Italian Cultural Studies, which became also the first cohesive collection of essays to explore what this label might actually mean (Parati and Lawton 2001). By serendipity, and outside the field of Italian studies and academia, in 1999 Giannino Malossi edited Volare. The Icon of Italy in Global Pop Culture, in conjunction with an exhibition by the same title held at Stazione Leopolda in Florence as part of the program Fashion Engineering Unit, dedicated to research on fashion cultures. Malossi approaches 'Italy, not Italy as it is, but Italy as it is imagined to be' (1999: 24), and provides a left-of-field and innovative contribution to questions of cultural practices, identification processes, pop/high culture distinctions, media, consumption, fashion, and sport. In 2001 Barański and West's Cambridge Companion to Modern Italian Culture opened up the idea of 'Italian culture' to a variety of critical approaches and cultural productions, cutting through false dichotomies of high versus popular cultural forms and providing a widespread introduction to the cultural study of post-unification Italy. In Italy itself the journal Studi Culturali (www.studiculturali.it) was first published in 2004 and has since become a point of reference in the field.

All of these texts and initiatives constitute a precious library and genealogical resource for those of us who teach and research Italian contemporary cultures, whether in Italy or elsewhere. Building on these studies, a decade after the first published formulations concerning the very idea of Italian cultural studies appeared, this special issue of Portal aims explicitly to reopen the debate and see how, if at all, the field has changed in the intervening years.

The articles included in this special issue constitute a wide-ranging and multifaceted contribution to Italian cultural studies, migrating at times from and/or between the concerns upheld in traditional departments of Italian Studies to non-area and transnational studies. While building on a variety of disciplinary genealogies the articles assembled here are linked by a shared preoccupation with social change as inscribed in broad cultural practices rather than with specific cultural texts. In this sense this special issue of Portal engages with Italian culture as sets of processes that come into being in 
the grip of tractions between local knowledges and global imaginaries, national and international capital flows, and intersections across the cultural landscape. It is clear at first glance that the Italy written here is a mutant, displaced, provincialized and diasporic place, one imagined elsewhere by the authors. Even Alice Mattoni, who writes her contribution to this issue from Florence, does not work from a base inside an Italian university.

The nuances and rhetoric of social change during the Italian miracolo economico in the 1960s are examined by Ailhlin Jane Clark in her article on food consumption in Southern Italy. 'Changing Consumption, Changing Consumers: An analysis of Changing Food Consumption in Southern Italy in the Mid-twentieth Century,' is based on interviews Clark conducted with people on the Amalfi coast. The article argues against the grain of traditional narratives that identify change in consumption with change in the availability of products. Clark concludes that the adoption of 'new' consumable and durable food items along the Amalfi coast was made possible by a local communitarian disposition to accept, negotiate and integrate newness into pre-existing habits and traditions and in pragmatic relation to geographical surrounds.

The messy business of constructing shared meanings in an Italy that has always been home to minorities, and that over the last few decades has very rapidly become diasporic, multiethnic and multiculturalism is explored by John Kinder. In his analysis of the Italian language debate, 'Language and Identities: The Exceptional Normality of Italy,' Kinder proceeds from Gramsci's famous note on the link between the surfacing of language debates and the pull towards some form of cultural hegemony. Kinder argues that the questions opened up by those debates in terms of identity and otherness reflect frictions internal to languages themselves. Examining Italy's linguistic richness and diversity Kinder redresses the perception that Italy presents a national case of constant exceptionality, and argues instead that linguistic confusion is at the core of Italy and hence Europe itself. Myths such as the story of Babel point to a shared imaginary of linguistic diversity while illustrating the paradox of creating shared meaning through encounters with differences. According to Kinder, the tensions surfacing in the ongoing discussion about an Italian language canon both reflect and confirm the frictions and contradictions present in current Italian identity debates. 
In Kinder's article the first language planner and policy maker to emerge in a region that would become known as Italy was Dante, a figure able to mediate between different layers of language from the supra-national Latin to volgare to vernaculars. However, in Joseph Pugliese's 'Whiteness and the Blackening of Italy: La Guerra Cafona, Extracomunitari and Provisional Street Justice,' Dante becomes the symbol of mythical purity, of Italian monoglossia. The marble statue of Dante in Piazza Dante in Naples, now a complex palimpsest of graffitied commentary, provides Pugliese with the opportunity to observe counter-responses to the monoglossic paradigm of heteroglossia. The encroaching graffiti on the Dante statue, he suggests, challenges not only the longing for a pure language but also the Northern Italian desire for cultural hegemony. Moving away from the Piazza Dante, Pugliese maps vernacular politics of resistance across a wide timeframe that spans southern brigandage, a practice of insurrection against the Italian nation in the immediate post-unification (1861) years, and contemporary hip hop. That music and cultural form enables Pugliese to draw an arc linking counter-nationalist movements in the Global South, and to find political and cultural connections between immigrants and Southern Italians. Pugliese concludes his article, by contrast, with an analysis of the 2008 Lega Nord election campaign posters, arguing that the formation of a hegemonic Italian identity rests, historically, on the premises of the exclusion of Southern Italians and extracomunitari alike through the deployment of the 'invisible visibility' of whiteness.

Creative practices of contestation and conflict are also examined by Alice Mattoni in her essay on the role of media in recent struggles against precarity in Italy, 'Serpica Naro and the Others. The Media Sociali Experience in Italian Struggles Against Precarity.' Mattoni, arguing that the role of social movements includes the production of symbolic resources that, in turn, create new forms of collective identities, focuses on media sociali, or socialized, distributed, media. With this label, coined by the Milanese group the Chainworkers Crew, Mattoni identifies links between a range of case-study practices: the creation of San Precario, the new patron saint of precarious workers; a series of political actions around Milan Fashion Week in 2005, involving the construction of a spoof fashion designer, Serpica Naro; and the invention of a set of super-heroic figures, Gli Imbattibili. Each case study enables Mattoni to explore the mechanisms through which i media sociali produce forms of political socialization and, according to some activists, of conflict through networking and politics of recognition. 
Tiziana Ferrero Regis's contribution, 'Fatto in Italia: Refashioning Italy,' discusses the role of the fashion system, and of the 'made in Italy' trend, in the recovery from the shrinking economic growth of the 1970s. Fashion, she argues, played a key role in the definition of a new modes of Italian identification after the anni di piombo, an era defined by the domination of rampant consumerism at the expenses of political engagement. Linking the making of 'made in Italy' with the rise of Milan in the 1980s as capital of the ready made, the success of the Socialist party (1983-1987), economic growth and riflusso, Regis contends that fashion and design in the 1980s became the main site for the rearticulation of Italianness. As such, fashion and design replaced other cultural industries, in particular cinema. Providing a precise and wide ranging contextualized analysis of fashion as it was inscribed in the 1980 s economic system and political climate, Regis proposes that Italian identity was redefined through fashion, and that 'Made in Italy' became a powerful new cultural model for the entire nation.

Finally, the global connections of contemporary Italian design are explored by Emiko Okayama and Francesco Ricatti in 'Tokidoki, Cute and Sexy Fantasies between East and West: Contemporary Aesthetics for the Global Market.' The article considers the work of the Italian born, Los Angeles-based designer Simone Legno, whose creations are predicated on an invented world of cute, sexy figures inspired by a range of Japanese aesthetic styles and traditions. The idea of Japan deployed by Legno is a fantasy world influenced by childhood memories of Japanese anime, which were reproduced and repackaged for Italian television in the 1980s, and by a global 'cute' (kawaii or il carino) aesthetic emanating from Japan that has found avid consumers throughout East Asia and beyond that region. Tokidoki, the authors argue, is the result of the meeting, assemblage and reinvention of multiple cultural imaginaries. Legno's design world thus raises questions about the nature of 'the national' Italian cultural heritage, as well as about the processes that at once impel and defeat attempts to define certain globally circulating cultural products as 'Italian' only.

Those questions meld with those underwriting this special issue of Portal. That is: how might Italian cultural studies in the twenty-first century best respond to the making, imagining and writing of multiple Italies within Italy itself and in the diasporic, provincialized Italies, and between those entities, with a perspective that is both global and informed by specific local knowledge? 


\section{Reference List}

Allen, B. and Russo, M. 1997, Revisioning Italy. National Identity and Global Culture, University of Minnesota Press, Minneapolis and London.

Barański, Z. G., and West, R. J. (eds) 2001, The Cambridge Companion to Modern Italian Culture, Cambridge University Press, Cambridge.

Dombroski, R., and Cervigni, D. 1998. Italian Cultural Studies, Annali d'Italianistica (16).

Forgacs, D., and Lumley, R. 1996a, 'Introduction: Approaches to Culture in Italy,' in Italian Cultural Studies: An Introduction, (eds) D. Fogacs and R. Lumley, Oxford University Press, Oxford, 1-12.

Forgacs, D. and Lumley, R. (eds) 1996b, Italian Cultural Studies: An Introduction, Oxford University Press. Oxford.

Galli Stampino, M. 2001. 'What We Talk About When We Talk About [Italian] Cultural Studies, and Why (With Apologies to Raymond Carver),' in Italian Cultural Studies, (eds) G. Parati and B. Lawton, Bordighera Press, Boca Raton, FL, 27-51.

Malossi, G. 1999, Volare, The Icon of Italy in Global Pop Culture, The Monacelli Press, New York. Parati, G. and Lawton, B. (eds) 2001, Italian Cultural Studies, Bordighera Press, Boca Raton, FL.

Pireddu, N. 2001, 'The Anthropological Roots of Italian Cultural Studies,' in Italian Cultural Studies, (eds) G. Parati and B. Lawton, Bordighera Press, Boca Raton, FL, 66-90.

West, R. 2001. 'The Place of Literature in Italian Cultural Studies,' in Italian Cultural Studies, (eds) G. Parati and B. Lawton, Bordighera Press, Boca Raton, FL, 12-26. 